Original scientific paper

Submitted: 2020-11-16

doi:10.5937/nabepo25-29274

Published: 2020-11-30

\title{
SOME PSYCHOLOGICAL IMPACTS ON JUDGING IN CRIMINAL CASES WITHIN THE SUPREME COURT OF CASSATION OF THE REPUBLIC OF SERBIA ${ }^{1}$
}

\author{
Dragutin Avramović ${ }^{2}$ \\ University of Novi Sad, Faculty of Law, Serbia
}

\begin{abstract}
Following hypothesis of Andrew Watson, American professor of Psychiatry and Law, the author analyses certain psychological impacts on behavior of judges and examines the relationship between their idiosyncrasies and their judicial decisions. The survey encompasses the judges of Criminal Department of the Supreme Court of Cassation of the Republic of Serbia and, also, for comparative reasons, the judges of Criminal Department of the First Basic Court in Belgrade. Considering the main issues there is no great discrepancy between answers given by the judges of the Supreme Court and those of the Basic Court. Most responses of the Serbian judges deviate from Watson's conclusions, namely: they do not admit that they feel frustrated due to heavy caseloads, the significant majority of judges are reluctant to acknowledge their prejudices and influence of biases on their ruling, the significant majority of judges are not burdened with the idea of possible misuse of their discretion, they nearly unanimously deny that public opinion and media pressure affect their rulings, etc. Generally, the judges in Serbia are not willing to admit that they cannot always overcome their own subjectivities.
\end{abstract}

Keywords: psychoanalytic jurisprudence, judicial discretion, American Legal Realism, Jerome Frank, Andrew Watson.

1 This paper is a result of the Scientific Research Project "Development of Institutional Capacities, Standards and Procedures for Fighting Organized Crime and Terrorism in Climate of International Integrations". The Project is financed by the Ministry of Education, Science and Technological Development of the Republic of Serbia (No. 179045), and carried out by the Academy of Criminalistic and Police Studies in Belgrade.

2 Corresponding author: d.avramovic@pf.uns.ac.rs. 


\section{INTRODUCTORY REMARKS}

Psychological influence on decision-making by judges is an old, popular and provocative topic. Multidimensionality of that legal phenomenon necessarily requires a multidisciplinary approach. The need to associate law with other disciplines was predominantly recognized during the second half of the $20^{\text {th }}$ century. This period saw the emergence of a number of interdisciplinary theoretical strategies, like those linking law with economy (Economic Analysis of Law or Law and Economics), ${ }^{3}$ with literature (Law and Literature Movement), ${ }^{4}$ and with psychology. However, a theoretical approach labelled as "Psychoanalytic Jurisprudence" attracted a more serious scientific interest no sooner than in the 1960s and 1970s, mostly owing to the following papers (Bienenfeld, 1965; Goldstein, 1968; Schoenfeld, 1964). But it became established as a mainstream concept as soon as in 1971 due to the profound and comprehensive contribution by Albert Armin Ehrenzweig in his "Psychoanalytic Jurisprudence" (Ehrenzweig, 1971; Novak, 2016; Vračar, 2000). One of the founding fathers of psychoanalytic jurisprudence was an American judge and legal philosopher, Jerome Frank (1889-1957). ${ }^{5}$ That line of thinking fitted well to the American Legal Realism Movement which Frank was developing, promoting the idea that research of jurisprudence should include empirical evidence typical of natural sciences. His denial of law as a system of predictions and logic, launched in his famous book Law and the Modern Mind of 1930 (Chase, 1979; Frank, 2009), "fell like a bomb" in old-style legal theory and philosophy. He claimed that judicial decisions were more influenced by psychological inputs than by objective data. Therefore his central research was aimed at revealing the process of judicial reasoning and decision-making in the psychological context and with psychological explanations.

From the point of view of legal science and practice, it may be crucial to consider all possible factors that affect the law making process and particularly the process of applying the law. The man, not a machine, creates and applies the law. Is it legitimate and realistic to expect of a man to rise above all his feelings, subjectivities and biases, surpass his own limits, act like a God, and make a completely objective decision in every single concrete case? Consequently, is it realistic to predict every single legal outcome? Which psychological elements, which stressors - biological causes, social conditions, external stimuli or events - influence judge's behaviour and decision in a particular case? Some authors (Sutherland \& Cressey, 1978) notice that, for example, in ordering punishments judges walk a thin line between two conceptions of justice/ injustice - 'law enforcement principle' and the 'adjustement principle'. A judge who leans too far toward uniformity and law enforcement, as well as the one who leans too toward disparities of sentence will not display 'the judiciousness, wisdom and compassion' that citizens ex-

3 Most prominent representatives and founders of this approach were the Chicago School of Law professors Ronald Coase and Richard Posner.

4 Its forefathers and representative figures were predominantly James Boyd White and Richard $\mathrm{H}$. Weisberg.

5 Important impetus to psychological jurisprudence was given much earlier by Polish-Russian legal philosopher Leon Petrazycki. 

within the Supreme court of cassation of the Republic of Serbia

pect. Those authors claim that "Judges' judicial and sentencing behaviour is influenced by participation in social relationships, just as the behaviour of other persons is influenced by their social participation" (Sutherland \& Cressey, 1978: 456). However, some researches lead to different conclusion - that judicial background has little direct influence on sentencing behaviour (Myers, 1988). Many other possible theoretically well sounded and quite well founded answers could be offered on the basis of contemplation. But the goal of this inquiry is to seek some answers on a more pragmatic basis - the analysis of attitudes of judges in criminal cases in the Republic of Serbia towards some clearly defined questions in accordance with the questionnaire prepared by the author of this paper.

Some theoretical surveys have pointed to the necessity of undertaking an empirical research to test the above mentioned questions (Avramović, 2012; Avramović, 2018; Frank, 2009; Konečni \& Ebbesen, 1984; Nagel, 1982; Sheleff, 1986; Watson, 1988). Some assumptions constitute the main hypotheses of this research, namely: subjective features (personality of a judge) affect judicial decisions to a great extent; legal outcome of a concrete case is relative and cannot be predicted with certainty; the impact of different psychological elements on judicial decision depends on judges' age - in other words, it is related to their experience; there is a kind of convergence between the two great legal systems (common law and continental law) - in continental law countries (including Serbia), judges are increasingly becoming law-makers, rather than just mere law-appliers. The selection of these hypotheses probably derives from the author's previous theoretical research and from his own, regrettably quite short, practice completed in the first level court as a trainee.

\section{THEORETICAL FRAMEWORK OF THE RESEARCH - FOLLOWING THE PATH OF ANDREW WATSON}

Application of law involves at least a few steps: establishing the facts of the case with a certain degree of reliability, selecting the legal norm to be applied, interpreting its meaning (interpretative challenge), and the final decision shaping. In every phase of the law application process there is room for subjective evaluations by the judge, which opens the whole process up to different psychological impacts and challenges.
Findings of the American professor of Psychiatry and Law, Andrew Watson, one of the architects of scientific discipline Law and Psychiatry, ${ }^{6}$ are appropriate to serve as theoretical background for the analysis of basic hypotheses selected to be tested in this research (Watson, 1988). The basis for the analysis are the answers to the survey questions given by the criminal judges of the First Municipal Court (Basic Court) in Belgrade, and the judges of the Crimi-

6 Andrew S. Watson (1920-1998) had a very interesting intellectual background. Firstly, he finished undergraduate studies in zoology, and after that medical, and psychoanalytic studies. He was an assistant professor of Psychiatry and associate professor of Psychiatry and Law at the University of Pennsylvania. Since 1959 he was engaged at the University of Michigan. In 1966, he became a full professor in both law and medicine, and after retirement 1990, emeritus in both disciplines. Beside his academic career he had private psychiatry practice. 
nal Department of the Supreme Court of Cassation of the Republic of Serbia. To enable comparison and test the results of the research more profoundly, we held additional interviews with the criminal judges of the First Municipal Court (Basic Court) in Belgrade, be it one of the biggest and most significant first level courts in Serbia.

Watson came to his conclusions following Jerome Frank, who was one of the most radical and famous representatives of the so-called American Legal Realism, a theoretical view which is still quite popular in the US (Frank, 1953; Frank, 1973; Frank, 2009; Vukadinović \& Mitrović, 2019). However, his attitudes were so rigid that scholars often have labeled Frank's idea as "digestive jurisprudence" due to his famed statement that legal outcome of a particular case could sometimes depend on whether the judge was hungry or overeaten during the trial. Due to his extreme view Frank was criticized even by his American fellow scholars who also belonged to Legal Realism Movement (Cohen, 1935; Llewellyn, 1931). Namely, Frank's starting point is the "basic myth of legal certainty". He roots "the basic myth" back in childhood, because infants have a fear of the unknown and strive for safety and certainty. Children overcome those fears by reliance on their "omniscient, omnipotent and infallible father". Eventually, as they grow older and face reality, the belief in an omnipotent father disappears. However, Frank observes that many mature people keep that infantile need even in their adulthood. They search for their father-substitutes not only in different spheres of life and persons (such as the priest, the ruler, leader of a certain group), but also in law and, accordingly, in the personality of the judge. Then they perceive the judge as an infallible being, a man whose decisions are completely predictable and who guarantees security in the unsecure world. Thus, even among the adults originates or survives "an illusion of legal certainty" (Frank, 2009: 17). Despite their rigidness, Frank's attitudes should not be neglected and proclaimed as valueless. At least he had courage to point to something that all lawyers, particularly judges, tend to hide even from themselves - the fact that the outcome of a concrete case is often relative. The same phenomenon was observed by Watson, who decided to further develop Frank's idea from the psychological point of view.

Whereas Frank was satisfied with elementary psychoanalytic explanations of judges' behaviour grounded on basic ego defending mechanisms (like suppression and rationalization), Watson tries to step forward and extend research to some other psychological means that judges use to maintain the myth of legal certainty, and consequently make themselves feel comfortable and calm (Watson, 1988: 937-938).

Watson was aware that his research would not produce more significant results in terms of eradication of identified predispositions of people that affect ruling by judges beyond any doubt. $\mathrm{He}$ was satisfied with awaking subjectivities among judges, by generating a desire in the judge to "learn about his psychological self and optimize his chances for dealing responsibly with all of his personal quirks, biases, and inclinations" (Watson, 1988: 960). The hypotheses examined in this research are mostly based on the dominant psychological stressors pointed by Watson. 


\section{EXAMINATION OF PARTICULAR PSYCHOLOGICAL IMPACTS ON BEHAVIOUR OF JUDGES IN THE REPUBLIC OF SERBIA}

The author is well aware that inquiries as a method of research in social sciences comprise some weaknesses but their major strenght is that they are the only mean to reach some figures, particularly those which are products of psychological processes. Also, the author knows that the sample used in this research is relatively small (projected to be expanded in the future research) and that it comes from the jurisdiction of a single country - Serbia. The responses came from 12 criminal judges of the Supreme Court of Cassation of Serbia and 19 judges from the first level court (the First Basic Court) in Belgrade. One may object that the sample is small. However, the Supreme Court of Cassation has within its Criminal Department 13 judges and only one of them did not take part in the survey. The Criminal Department of the First Basic Court in Belgrade (out of three Basic Courts in Belgrade) consists of 22 judges of which only three opted out. This high percentage of judges deciding to take part in the study was quite encouraging. The overall impression is that they cooperated in the research with enthusiasm. Quite ob- viously, judges were interested to share their thoughts on those issues and they understood the importance of those questions. In any case, they accepted to make a kind of self-analysis of their feelings and professional behaviour. Most of them were ready to face those queries, make a self-portrait and, possibly, reexamine their professional performance. The reliability of the results is increased as the group of interviewed individuals was homogenious, it encompassed highly educated people with great personal responsability, established social sensibility, the persons who are well aware of the importance of that research. Also, the reasearch was not conducted individualy and randomly but institutionaly and systematically. And last but not least, the survey was fully voluntary and anonymous. Both Frank and Watson had grounded their conclusions firstly relating to the judges in criminal cases, and therefore this inquiry encompassed only that category of judges.

The survey questionnaire was mostly shaped to meet the abovementioned and other assumptions determined by Watson.

\section{The image of a judge}

Like any other person, judges care quite a lot about the opinion that their colleagues have of them. Obviously, every judge is under constant "observation" by his fellow colleagues. He is expected to be objective, honest, courageous, kind, emotionally stable, firm and at the same time sensitive, empathetic, patient, and highly intellectual, with a sense of fairness. Expectations are enormous. But every person, including a judge, retains in himself his deeply rooted values, and affinities and prejudices that he has accumulated and maintained for years. To preserve the wishful image of a "fair and just judge", among other things, a judge sometimes departs from his own implanted values. And, of course, it can sometimes generate an immense internal conflict he could be facing. Addi- 
tional internal conflict can be caused by a primordial desire to be altruistic; however, the empathy disappears with time, as judges deaden emotionally, by continually doing the same type of job, so that they perceive a man in prison in the same way as a man in the living room (Watson, 1988: 941-943).

In responding to the question Do you care about the opinion of other judges about you?, eight judges of the Supreme Court answered "yes", one said "no", one was "not sure", while two did not give any answer. On the other hand, 10 judges of the Basic Court responded "yes", seven said "no", while two were "not sure". The answers suggest that the Supreme Court judges care a bit more about their fellow colleagues' impression of them than their younger first instance counterparts do. By summing the answers of judges from the two courts, we arrive at 18 judges responding "yes" (62.97\%), eight saying "no" (27.59\%), three "not sure" (10.34\%) and two not responding at all. Consequently, the prevailing answer to this question corresponds well to Watson's conclusion that the opinion of other judges affects a judge himself.

The second question was: Does the growing caseload make you frustrated? Two judges of the Supreme Court responded "yes", eight said "no", one was "not sure" and one did not answer, while among the Basic Court judges, six responded "yes", eleven said "no" and two were "not sure". The issue of high caseloads affects more the Basic Court judges, as expected, because they have to deal with substantially greater number of cases. Nevertheless, one should bear in mind that the caseload of the Supreme Court, having had jurisdiction over the entire country, is also substantial, and that those cases are more complicated and demanding (Supreme Court of Cassation, 2019). Altogether, eight judges answered "yes" to this question $(26.67 \%), 19$ responded "no" (63.33), while three were "not sure" (10\%). This result does not fit Watson's attitude that continual case overload frustrates judges.

The last question about the judge's self-image read: Do you sometimes have a feeling of empathy towards the accused person? In the Supreme Court, only one judge said "yes" (8.33\%), eight answered "no" (66.67\%) and three opted for "sometimes" (25\%). Within the Basic Court, eight judges said "yes" (42.11\%), two responded "no" (10.53), and nine opted for "sometimes" (47\%). These data suggest that the feeling of empathy is considerably less common among the experienced judges of the Supreme Court (although it could also be explained by the lack of personal contact with the accused person). Nevertheless, the differences in explanation are remarkable. The attitude of the Supreme Court judges leads to Watson's assumption that the absence of empathy is common among judges. However, taken together, the answers of the Supreme Court and Basic Court judges neither confirm nor conflict with Watson's attitude - nine judges answered "yes" (29.03\%), ten said "no" (32.26\%), and 12 stated "sometimes" (38,71\%). Judge's experience seems to be a crucial factor that could move the final conclusion on this question towards Watson's statement. 


\section{Personal biases}

Watson believes that not every man, and consequently not every judge, denies the existence of certain prejudices, being aware that it is psychologically normal. Already as children, we acquire cognitions of good and bad that we implant in our values, creating in that way a kind of "archaic biases", as he names it. By getting older people are becoming more rational and, accordingly, some of the old prejudices are disappearing, while new political, social, economic and other ones are replacing them. In any case, the childish black and white vision of the world is vanishing. A judge must face his own prejudices to be able to resolve cases in a fair manner, overcoming personal biases. The demand Iudex aequitatem semper spectare debet, postulated back in Roman law, is still authentic. And this is precisely the point where new emotional conflict arises within a judge - between the "images of how he thinks a judge should behave versus how he is inclined to decide in response to old values retained" (Watson, 1988: 945).

The first question on the track of judges' prejudices was: Do you recognize any kind of prejudice in your behaviour? Only one judge of the Supreme Court responded "yes" $(8.33 \%)$, ten of them responded "no" (83.33\%), and one was "not sure" (8.33\%). Basic court judges painted a bit different picture: eight of them responded "yes" (42.11\%), nine said "no" (47.37\%), and only two were "not sure" (10.53\%). This structure of answers may look a bit strange. Curiously, while almost every experienced judge of the Supreme Court denies the fact that every man, including the judge, has some kind of prejudices, younger judges of the Basic Courts feel quite differently. One possible explanation, however, for this strange picture is that the experienced judges who recognize prejudice spontaneously try to get rid of it and behave like they do not have any. Nevertheless, in sum, nine judges of both courts answered "yes" (29.03\%), 19 opted for "no" (61.29\%), and three were "not sure" (9.68\%). Thus we arrive at the dominant answer that judges do not recognize their own prejudices, which contradicts one of the basic Watson's statements.

The next question that followed logically was: Could you completely distance yourself from your prejudices during the ruling process? Nine judges of the Supreme Court answered "yes" (75\%), two said "no" (16.67\%) and only one was "not sure" (8.33\%). As for the Basic Court, 14 judges responded "yes" (73.68), only one said "no" (5.26\%), and four were "not sure" $(21.05 \%)$. It is particularly significant that all nine judges of the Basic Court who have responded negatively to the previous question (those who declared themselves as not at all prejudiced) have confessed here that they are able to distance themselves from prejudices in judging! Similarly, out of 10 judges of the Supreme Court who denied having prejudices, eight responded that they could distance themselves from bias when judging. Finally, the result in total shows that 23 judges responded "yes" (74.19\%), only three "no" (9.68\%), while five were "not sure" (16.13\%). It contradicts Watson's assumptions even more. 


\section{The need to decide}

A particular type of psychological pressure on judges is the need to decide many issues, concerning not only the verdict but also other different decisions in a particular case (especially the procedural matters, such as determining the date of hearing, the court summons, etc.). Namely, the final outcome may depend on the resolution of some trial flow issues that may look quite bizarre at first glance. A rudimentary social tendency that Frank labels as the basic legal myth of "hunger for certainty in law" and "craving for a non-existent and unattainable legal finality" is tumbled to the judge who is expected to meet those public expectations. So, along with his internal psychological pressure to achieve legal certainty, he also faces social pressure. "A judge may well seek to convince himself that he has those oracular powers that would enable him to find certainty in order to alleviate his own doubts. To whatever degree he falls prey to that temptation, he will operate in a world of pure delusion" (Watson, 1988: 946).

Also, when facts of the case or related laws lead a judge to the conclusion that he considers unjust, he has to resolve psychological conflict or find in some way other facts as relevant or use a creative interpretation of the legal norm. That unavoidable task, in Frank's and Watson's view, a judge will perform either consciously or unconsciously, whereby he will resort to a kind of rationalization (Watson, 1988: 948). "Not infrequently this means that in writing his opinion he (judge) stresses (to himself as well as to those who will read the opinion) those facts which are relevant to his conclusion - in other words, he unconsciously selects those facts which, in combination with the rules of law which he considers to be pertinent, will make 'logical' his decision" (Frank, 2009: 145).

Considering the psychological state of the judge's mind when making a decision, Watson points to another source of stress - revival of the childish phantasy of omnipotence. Among mature people, the fantasy of omnipotence vanishes due to the pressure of reality. However, the power vested in judges could revive the old conviction that he must always be right if he just works studiously enough. "Unless such a judge has lost his sense of reality completely, the ongoing press of daily events should pull him back to the awareness of his human fallibility and hopefully, will allow him to take a more humble approach towards his tasks" (Watson, 1988: 951).

In accordance with these conjectures, the subsequent question was: Do you feel pressure due to the expectation that you are always obliged to make a decision? In the Supreme Court of Serbia, all 12 respondent judges answered "no", while four judges of the Basic Court answered "yes", 14 said "no" and one was "not sure". Evidently, a significant majority of judges of the two courts have given a nearly unanimous answer - that they do not feel that kind of pressure - which contradicts Watson's opinion.

The next question was Do you rely upon your own feelings (intuition) during the decision-making process? Nine judges of the Supreme Court responded positively (75\%) and only three negatively (25\%). At the Basic court level, 11 judges answered "yes" (57.89\%), six said "no" (31.58\%) and two were "not sure" (10.53\%). It could have already been expected that 
more experienced judges of the Supreme Court would more easily admit that intuition affects their decisions; curiously, however, a significant number of younger judges did the same. Taken all answers together, it is evident that the majority of judges acknowledge the influence of intuition on their decision-making process, which is the finding that aligns with the Watson's conclusions.

Regarding the question Do you think that judges are law-makers in the Serbian legal system?, nine judges of the Supreme Court responded positively (75\%), only one negatively (8.33), while two were uncertain (16.67\%). Nine judges of the Basic Court also responded positive- ly $(47.37 \%)$, six did not agree with the statement $(31.58 \%)$ and four were uncertain $(21.05 \%)$. Reasonable expectation that younger judges do not think that they create law was confirmed; however, taken together, the results show that 18 judges accept that perception (58.06\%), seven of them reject it (22.58\%) and six of them are uncertain about it. It not only confirms the Watson's statement that judges do create law, but it also proves that two great legal families - common law and continental law - are converging, and particularly that case-law is becoming a formal source of law in the civil law countries. This opinion is strongly supported by the great majority of the experienced Supreme Court judges.

\section{Stress from problems with power}

In performing judicial duties, the judge certainly has very wide powers. Although their framework is somewhat broadly defined by legal rules, and the code of judicial ethics, independence of the judge is still great. Considering the broad right of discretion that judges exercise, Watson believes it to be another cause of internal conflict. For example, judges may react differently to an aggressive impulse of a party or a lawyer in the case. With their powers and responsibilities in mind, they could respond by calm behaviour, controlling their reaction (using the ego defense mechanism of reaction formation), or they may lose control and react improperly and aggressively, reflecting the repression or denial of the restraint a judge is supposed to employ. Although every judge knows that he is expected not to react improperly, his strong psychological impulse causes a strong internal conflict within himself (Watson, 1988: 952-954).
Bearing in mind the stressors related to judge's powers, the following questions were employed for testing.

Are you aware how wide the judge's discretion that you dispose of is? Within the Supreme Court, all 12 judges responded affirmatively, while within the Basic Court, 16 judges responded positively and only three of them were uncertain. Nearly all judges are aware of that privilege and burden.

Do you react to aggressive impulses of parties or lawyers restrainedly? Nine judges of the Supreme Court declared that they do not remain calm, two of them said "yes", and one did not respond. Conversely, only five judges of the Basic Court declared that they do not remain calm, ten of them stated that they do, and four answered "sometimes". It can be concluded that older and more experienced judges feel free to express their emotional reactions to aggressive approach of other parties (it is likely that they are diminish- 
ing their internal psychological conflict). On the other hand, younger judges tend to suppress their reaction. However, one must bear in mind that Supreme Court judges have little contact with parties and lawyers; hence, their answers are based on their previous experience in trial courts. Nevertheless, the responses correspond with Watson's thesis that judges react differently to external aggressive impulses which in any case cause in them a kind of internal conflict.

Are you burdened with the idea that you could misuse your judicial discretion? Only three judges of the Supreme Court said "yes" (27.27\%), eight of them responded "no" (72.73\%) and one did not respond at all. Quite similarly, only one judge of the Basic Court said "yes" (5.26\%), 17 responded "no" (89.47\%) and one was "not sure" (5.26\%). The predominant answer was negative - most of the judges are not burdened with the idea of possible misuse of judge's discretion, which deviates from the Watson's proposition. However, it is quite significant that the majority of judges responding to the previous question answered that they relatively rarely stay calm upon aggressive impulses by parties or lawyers, concurrently feel quite relaxed regarding the possible misuse of judge's discretion. An observation by a prominent representative of the Scandinavian Legal Realism, Alf Ross, seems to offer a possible answer to this issue: "It may be an interesting problem of social psychology why one should wish to conceal what really takes place in the administration of justice. Here we must be content to state that it seems a universal phenomenon to pretend that the administration of justice is a simple logical deduction from legal rules without any evaluation by the judge" (Ross, 1959: 154).

\section{Stress from sentencing tensions}

A particular kind of pressure upon a judge emerges during the process of bringing a verdict. Along with numerous personal reasons (Frank would call them "idiosyncrasies" - peculiarities, conscious or unconscious values of an individual), there comes additional tension from the public, particularly in issues of "convicted culprits". The community pressure could be even stronger for those mindful of their professional career, re-election or appointment to a higher court. In a word, Watson is convinced that influence of the public is inevitable and that it causes an additional internal conflict for a judge (Watson, 1988: 954-955).

This conclusion is more or less confirmed in the interview with the President of the Supreme Court of Cassation of Serbia, Judge Dragomir Milojević, who answered a similar question: "It is sure that media announcements of arrests or publicizing that some cases are expected to be initiated do not ease the position of the judge to whom a "famed" case is assigned for adjudication. Media often proclaim in advance that someone is a great criminal, dangerous murderer, etc. Those public qualifications cause a heavy burden for the judge who is to handle such a case. Could it be related to political pressure? Perhaps yes, perhaps no. Either way, however, different types of pressure upon a judge do exist. And it comes not only from the person who gives this kind of statements, but also from those who publish it" (Milojević, 2019). 
A similar testimonial was given by the President of the Court of Appeal in Belgrade, who once said: "I would not be sincere if I said that I do not react, like any man, to different texts in newspapers when they are in any sense connected with judiciary. I only try to distance myself from those inputs as much as I can by relying on my long-standing experience" (Milenković, 2018).

Consequently, following these considerations, the question of the survey was: Does the public and media pressure affect your decisions? The results were amazing. Not a single judge of the Supreme Court said "yes", eight of them explicitly denied $(66.67 \%)$ and four were uncertain (33.33\%). Similarly, in the Basic Court, only one judge responded that the public opinion and media pressure do affect his decision (5.26\%), 17 responded negatively $(89.47 \%)$ and only one was uncertain. Thus, we obtained a nearly unanimous answer that the public and media pressure do not affect decision-making by judges. This finding strongly contradicts Watson's thesis, as well as the statements of the two presidents of the highest courts in Serbia. There are different possible reasons for the judges being so unanimous in answering negatively, and one of them is that they were not completely sincere.

3.6 Conflicts over personal needs versus professional demands

It is quite common, particularly in Serbia, that judges have a lot of cases and little time, making them unable to pay the same amount of attention to all cases. The continuous overloading of cases generates additional psychological pressure on judges, including the feeling of not being capable enough. Work pressure particularly affects judges of the perfectionist kind, who still have the fantasy of omnipotence. For Watson, it is clear that omnipotence of a judge is just an illusion and that a judge who continues to cherish that fantasy is inevitably faced with failure (Watson, 1988: 956).

In that context, the following question was formulated: Have you ever called into question your capabilities due to objective difficulties to give a verdict in due time? It is basically the question which could 'put on trial', to some extent, the judge's feeling of omnipotence (or 'phantasy of omnipotence'), as Watson calls it. The judges of the Serbian Supreme and the Basic Court were of similar opinion. Ten judges of the Supreme Court responded negatively, and only two of them did not respond. Likewise, 14 judges of the Basic Court responded "no", three of them answered "yes", and two were "not sure". Contrary to Watson's view, most judges in Serbia seem accommodated to that kind of pressure; they do not doubt their capabilities on that ground and many of them basically have the illusion of omnipotence.

The subsequent question in that context was: Is your private life affected by your work overload? A certain difference can be noted in the answers of the Supreme Court and the Basic Court judges. In the Supreme Court, four judges answered positively, three responded negatively, three were uncertain, and two did not respond at all. Nine judges of the Basic court responded that their private life is affected with their work pressure, eight decided to check the answer "no" and two of them were "not sure". Contrary to Watson's conviction that judges feel the pressure of workload in their private lives, the judges of the highest and the first level Serbian courts are quite divided in their answers; therefore, this examination can neither confirm nor deny Watson's thesis. 


\section{EXAMINATION OF POSSIBLE "JUDICIAL SELF-HELP” IN OVERCOMING PSYCHOLOGICAL TENSIONS}

Watson identified six major conflicting situations, stated above, which represent dominant psychological stressors. While not excluding other possible stemming grounds of stress, he believes that those situations are dominant in causing internal conflict in judges and, consequently, that it adversely affects the establishment of legal certainty.

Therefore he took a step forward tending to offer a therapy to prevent those problems, labelling it as "judicial self-help". The principal remedy for a judge's problems of psychological tension is to be able to resolve the conflicts which produced the tension (Watson, 1988: 957). His main suggestion for judges how to overcome those tensions is to develop self-awareness. He suggests different approaches, like conversation with family members and friends (but also psychotherapy, including systematical judicial training sessions), widening of the legal knowledge, dialogues with colleagues who have the same problem in order to understand that he or she is not the only one with a problem.

When they fail to resolve the internal conflicts and endless search to reach the just decision, judges usually resort to "mechanistic" approach to the application of law (Watson, 1988: 957). They are thus able to justify the concrete legal outcome strictly by law. Firmly relying upon the law, judges basically shift responsibility on it. This practice is a kind of "ego defense mechanism of projection", whereby a judge projects his discontent with the decision on someone else.

At the end of his study, Watson gives advice to lawyers - basically the one that they already know well: that it is essen- tial to get well-acquainted with the personality of the judge who is in charge of their client's case (Avramović, 2018).

These Watson's observations provided a basis for formulating the final set of questions for the questionnaire.

A. Would you accept psychoanalysis treatment in order to face your own prejudices and get to know yourself better? Three judges of the Supreme Court responded "yes", six opted for "no", two were "not sure", and one did not answer. At the Basic Court level, eight judges said "yes", six said "no" and five were "not sure". The result of the examination is curious: younger (Basic Court) judges were more open to that challenge than the older ones (from the Supreme Court). However, the judges of the two courts are quite divided on this issue. They evidently do not share on a large scale the opinion of Watson and Frank that psychoanalytic treatment of judges is helpful in gaining self-awareness, and that it could even be curative. That attitude of criminal judges in the Republic of Serbia is more in accordance with Posner's attitude that psychoanalysis of the judges, as suggested by Frank, is ridiculous because "apart from the time and expense involved, there is no basis for the claim that psychoanalysis has nontherapeutic value - for example, that it can improve the judgment of a normal person" (Posner, 2010: 118).

B. Have you ever hidden behind the law in order to avoid your own responsibility for the certain legal outcome? On this question, the answers of the two courts were more similar. Of the Supreme Court judges only two admitted that they have ("yes" $16.67 \%$ ), nine that they have not ("no" 75\%), and only one was 
uncertain (8.33\%). Only one judge of the Basic Court answered "yes" (5.26\%), 16 of them answered "no" (84.21\%) and two were "not sure" (10.53\%). Altogether, the result is quite consistent: the majority of judges of the two courts have answered that they never hide behind the law to escape responsibility for the legal outcome ( 25 of them $-80.65 \%)$, three were uncertain about it $(9.68 \%)$, and only three judges answered positively to this question $(9.68 \%)$. This statistics strongly contradicts not only Watson's but also one of the main Frank's conclusions.
C. The third question of that set was: Do you think that it is necessary to acknowledge to the law students the fact that concrete legal outcome is relative (uncertain)? Nearly all judges of the Supreme Court answered positively (only one said "no"). Correspondingly, 13 judges of the Basic Court were positive, three of them were uncertain, and three opted for "no". Although the question is quite delicate, particularly from the educational point of view, it may sound a bit strange that it triggered the highest degree of unanimity of all judges.

\section{CONCLUSION}

Significant discrepancy in answers of the Supreme Court of Cassation and the Basic Court judges is striking only in terms of empathy towards the accused person. The feeling of compassion is much more prevalent among younger judges of the Basic Court, while older and more experienced judges of the Supreme Court have nearly completely lost that kind of feeling. The answers of the Supreme Court judges are well in agreement with Watson's attitude that with the passage of time, and the accommodation to that profession and its challenges, the feeling of empathy is gradually disappearing. Myers also comes to a similar conclusion. His research shows that older judges are more punitive than younger judges (Myers, 1988).

The confirmed Watson's assumptions by the judges of both courts are not so numerous. Most judges, particularly those from the Supreme Court, do care about the opinions that their colleagues will have about them. Also, the majority of judges (especially of the Supreme Court) admit that they rely upon their intuition when they are deciding a case. A further general conclusion is that it seems that judges are more and more converting into law-makers within the Serbian legal system. It could be a specific kind of confirmation that continental legal systems are gradually and spontaneously embracing some common law system features. Finally, different reaction of judges to aggressive behaviour by parties or lawyers accounts for another Watson's assumption confirmed by this research. Judges are generally quite divided in their opinions concerning the impact of their workload on their private lives. Their answers can neither support nor deny Watson's thesis (neutral) about the inevitable impossibility of harmonizing professional duties with private needs and the frustration it causes for judges. Moreover, although Watson recommends that all judges should undergo psychotherapy in order to confront their own prejudices and develop self-awareness, judges are quite divided on that issue. Nevertheless, it is not possible to state that the Serbian judges have a high 
level of responsiveness in terms of the need for psychotherapy and self-awareness developing.

Responses by the Serbian judges to other issues deviate significantly from Watson's presumptions. There is a general unwillingness of judges to admit that they feel frustrated due to heavy caseloads. The significant majority of judges are reluctant to acknowledge their prejudices and influence of biases on their ruling. They unanimously reject the existence of psychological pressure due to the expectation that they must always decide and always be right in their decision. Although generally aware of how wide the discretion they enjoy, the significant majority of judges are not burdened with the idea of possible misuse of it. The judges nearly unanimously deny that the public opinion and media pressure affect their rulings. This denial is in contradiction not only with Watson's presumptions, but also with the public statements of the presidents of the highest courts in Serbia. Contrary to Watson's view, the majority of judges in Serbia do not have doubts in their capabilities and many of them basically maintain the illusion of omnipotence. Also, most of them asserted that they did not hide themselves behind the law and they were willing to accept their own responsibility for the outcome of the case.

However, generally and substantially, the attitudes of the Serbian judges are in agreement with Watson's, but most of all with Frank's general conclusion that most of the unpleasant experiences judges suppress into unconsciousness, maintaining in that way the myth of legal certainty. It all results in their unwillingness to break the 'basic myth' and generally admit the fact of uncertainty of a legal outcome and unawareness of their id- iosyncrasies' which undoubtedly more or less affect their decision-making. On the other hand, nearly all judges are of the opinion that law students must be acquainted with the fact of uncertainty of the legal outcome. Hence, it was possible to observe, and now it becomes obvious, that the majority of judges acknowledge their own role in the law-making process and consequently recognize the fact of uncertainty and relativity of the legal outcome. However, what judges do not want to recognize is the existence of a causal link between their idiosyncrasies (preconvictions) and their discretion on the one hand, and relativity of the legal outcome, on the other. In fact, the judges want to shift from themselves the potential responsibility for a certain legal outcome. If the majority of judges, as the inquiry has shown, have a role in the law-making process, if the legal outcome is uncertain and if the public opinion and media do not affect the court decision, then what does the legal outcome depend on, if not the judge himself? That observation is in accordance with Nagel's conclusion reached after examination of 313 state and federal supreme court criminal judges in the USA: "Because criminal cases frequently involve value oriented controversies, however, and because different background and attitudinal positions tend to correspond to different value orientations, there will probably always be some correlation between judicial characteristics and judicial decision-making in criminal cases" (Nagel, 1962: 339).

This research shows that judges do not readily admit that, like other people (and not like gods), they cannot always overcome their own subjectivities and their deeply rooted values. They are supposed to be a mere law - the "reason without passion". It seems that judges have great 

within the Supreme court of cassation of the Republic of Serbia

expectations from themselves, similarly as Rudolph von Jhering expected that a judge should not see before him the concrete individuals about whom he is deciding but abstract persons in the masks of plaintiff and defendant (Ihering, 1913: 297-298). A judge, a man made of flesh and blood, not a machine (or "judge Hercules" as Ronald Dworkin should say), can in some instances act irrationally and unpredictably, depending on his own current feelings and circumstances. Therefore, in those situations (but not only then, as we do not know when and what will induce a certain kind of reasoning) predictability of a legal outcome becomes mission impossible. Consequently, this research basically confirms the observation of Frederick Bernays Wiener that: "Judges are men, conscientious men, virtually all of whom work hard to eliminate personal predilections from the task of adjudication. Even so they are still human beings, they are not electronic automatons" (Bernays Wiener, 1962: 1024).

\section{REFERENCES}

Avramović, D. (2012). Odluka ili norma - slobodno sudijsko uverenje kao pretnja vladavini prava [Decision or Norm - Judicial Discretion as a Treat to the Rule of Law]. Collected Papers of the Faculty of Law in Novi Sad, 46(2), 311-325.

Avramović, D. (2018). Analiza predvidljivosti postupanja sudija - povratak mehaničkoj jurisprudenciji? [Predictive Analysis of Judicial Behavior - Return to Mechanical Jurisprudence?]. Crimen, 9(2), 155-167.

Bernays Wiener, F. (1962). Decision Prediction by Computers: Nonsense Cubedand Worse. American Bar Association Journal, 48(11), 1023-1028.

Bienenfeld, F. R. (1965). Prolegomena to a Psychoanalysis of Law and Justice: Introduction. California Law Review, 53(4), 960-1028.

Chase, A. (1979). Jerome Frank and American Psychoanalytic Jurisprudence. International Journal of Law and Psychiatry, 2(1), 29-54.

Cohen, F. (1935). Transcendental Nonsense and the Functional Approach. Columbia Law Review, 35(6), 809-849.

Ehrenzweig, A. (1971). Psychoanalytic Jurisprudence. New York: Oceana.

Frank, J. (1953). Judicial Fact-Finding and Psychology. Ohio State Law Journal, 14(2), 183-189.

Frank, J. (1973). Courts on Trial. New Jersey (USA): Princeton University Press.

Frank, J. (2009). Law and the Modern Mind. New Brunswick (USA) and London (U.K.): Transaction publishers.

Goldstein, J. (1968). Psychoanalysis and Jurisprudence. Yale Law Journal, 77(6), 1053-1077.

Ihering, R. (1913). Law as Means to an End. Boston: The Boston Book Company.

Llewellyn, K. (1931). Legal Illusion. Columbia Law Review, 31(1), 82-90. 
Milenković, D. (2018, September 16). Lični integritet čuva sudije od pritiska [Personal Integrity keeps Judges from the Pressure]. Blic. Retrieved February 3, 2019, from https://www.blic.rs/vesti/drustvo/intervju-dusko-milenkovic-predsednik-apelacionog-suda-licni-integritet-cuva-sudije-od/jtg05fm.

Milojević, D. (2019, January 1). Za silovatelje i napasnike kazne moraju biti oštrije [The Punishments for Rapists and Temters must be more severe], Blic. Retrieved February 3, 2019, from https://www.blic.rs/vesti/hronika/intervju-dragomir-milojevic-za-silovatelje-i-napasnike-kazne-moraju-biti-ostrije/egkkpkw.

Myers, M. (1988). Social Background and the Sentencing Behavior of Judges. Criminology, 26(4), 649-676.

Nagel, S. (1962). Judicial Backgrounds and Criminal Cases. Journal of Criminal Law, Criminology and Police Science, 53(3), 333-339.

Novak, M. (2016). The Type Theory of Law - An Essay in Psychoanalytic Jurisprudence. Switzerland: Springer International Publishing.

Konečni \& Ebbesen (1984). The Mythology of Legal Decision Making. International journal of Law and Psychiatry, 7(1), 5-18.

Posner, R. (2010). How Judges Think. Cambridge, MA (USA): Harvard University Press.

Ross, A. (1959). On Law and Justice. Berkeley-Los Angeles: University of California Press.

Schoenfeld, C. G. (1964). Psychoanalysis and Natural Law: Some Preliminary Observations. Howard Law Journal, 10(2), 277-284.

Sheleff, L. Sh. (1986). The Illusion of Law - Psychoanalysis and Jurisprudence in Historical Perspective. International Journal of Law and Psychiatry, 9(2), 143-158.

Supreme Court of Cassation. (2019). Annual Report on the work of the courts in the Republic of Serbia for 2018. Retrieved April 6, 2019, from https://www.vk.sud.rs/ sites/default/files/attachments/Annual\%20Report\%20on\%20the\%20Work\%20Of\%20 Courts\%202018.pdf.

Sutherland, E., \& Cressey, D. (1978). Criminology. Philadelphia: J. B. Lippincott Company.

Vračar, S. (2000). Zasnivanje psihoanalitičke jurisprudencije [Establishment of Psychoanalytic Jurisprudence]. In: S. Vračar, Preispitivanje pravne metodologije - nagoveštaji državno-pravnog integralizma [Review of legal methodology - hints of state-law integralism] (pp. 638 -658). Beograd: Pravni Fakultet u Beogradu-Službeni list SRJ.

Vukadinovic, G., \& Mitrović, D. (2019). Uvod u teoriju i filozofiju prava [Introduction to Theory and Philosophy of Law]. Beograd: Dosije.

Watson, A. (1988). Some Psychological Aspects of the Trial Judge's Decision-Making. Mercer Law Review, 39(3), 937-960. 